\title{
TESTICULAR STEROIDS AND BOAR TAINT
}

W.D. BOOTH

A.R.C. Institute of Animal Physiology, Animal Research Station, Huntingdon Road, Cambridge, UK

The testis of the mature boar is a large organ weighing as much as $500 \mathrm{~g}$, and occupying a conspicuous position in the scrotum. This fact may well have impressed those concerned with domestication of the pig, to the extent that they became aware of the testis being the source of determinants responsible for the development of male characteristics. Some of these characteristics were undesirable in so far as boars could develop a high libido, presenting husbandry problems, and the carcasses of older animals were often unpalatable in texture with a strong flavour and odour. Similar problems with the intact males of other meat producing animals, eventually led to the routine practice of castrating animals not required for breeding.

However, contrary to established opinion, the entire male pig at least to bacon weight, does not generally present the problems which castration was intended to eliminate. In fact there are considerable advantages to be gained both economically and gastronomically by producing meat from the young entire boar. During development, intact boars utilize their food efficiently, resulting in a more rapid growth rate and production of a leaner carcass than that of castrated boars or gilts. Although it is evident that testicular steroids are the active agents, there are few reports (Booth, 1980a) indicating which of the many steroids produced by the boar testis are involved in stimulating the development of male characteristics. The boar testis, like that of the stallion, is a prolific producer of oestrogen as well as androgens, and it is possible that oestrogens may act synergistically with androgens to produce both anabolic and androgenic effects.

A considerable body of evidence has accrued on the significance of one major group of steroids produced by the boar testis, namely the 16unsaturated $\mathrm{C}_{19}$ steroids (16-androstenes) (Gower, 1972; Claus, 1979; Booth, 1980b). Interest in these musk-smelling compounds was aroused initially when it was suggested that they may be responsible for the well-known taint or 'off odour' in the carcasses of mature boars as well as being involved in chemical communication (Sink, 1967). Subsequently, Patterson $(1968 \mathrm{a}, \mathrm{b})$ reported that, indeed, 16-androstenes are the major compounds responsible for boar taint. Furthermore these compounds when presented in aerosol form to oestrous pigs, facilitate the induction of the mating stance (Melrose, Reed and Patterson, 1971; Reed, Melrose and Patterson, 1974), and thus provide one of the first demonstrations of a mammalian pheromone which has been identified chemically. 
It is the aim of this review to give a detailed account of testicular steroids in the boar, with particular reference to the biosynthesis, metabolism and physiological role of androgens, oestrogens and 16-androstenes. A primary objective is to emphasize that the boar testis is not only a versatile and prolific steroid-producing organ, but also the knowledge gained through endocrine studies on this organ is important to the more practical aspects of reproduction and meat production in the pig.

\section{Androgens}

\section{TESTICULAR PRODUCTION}

Parkes (1966) noted that the testes of certain Chaeromorpha including the pig contain abundant interstitial tissue, and suggested that this could be related to a capacity of the boar testis to produce large quantities of steroid. Evidence for this suggestion already existed since Prelog and Ruzicka (1944) had isolated large amounts of the musk-smelling 16androstenes, $3 \alpha$-androstenol ( $5 \alpha$-androst-16-en- $3 \alpha$-ol) and $3 \beta$-androstenol

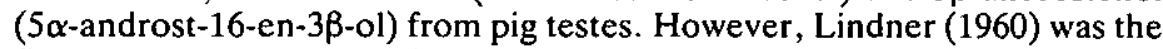
first to undertake a detailed study of testicular androgens in large farm animals including the pig. Lindner (1961) determined testosterone and androstenedione in the testis and spermatic vein blood of boars, and found a close correlation between the content of steroid in the testis and blood; the greatest amounts of steroid were found in mature boars. Large amounts of 17-ketosteroid existing primarily as the sulphate conjugate of dehydroepiandrosterone (DHA) (Gower, Harrison and Heap, 1970), were found in boar urine (Huis in't Veld, Louwerens and Reilingh, 1964; Lunaas and Velle, 1965; Raeside, 1965), and indicated that most of the 17-ketosteroids in boar urine originate in the testis. Later Liptrap and Raeside (1970) measured DHA and oestrogen in boar urine to evaluate the endocrine function of the cryptorchid testis. Although the excretion of these steroids was comparable to that in normal boars, Liptrap and Raeside (1971) subsequently showed that the cryptorchid testis was refractory to human chorionic gonadotrophin (HCG) until returned to the scrotum (Liptrap and Raeside, 1972).

The biosynthesis of testicular steroids in mammals has been reviewed by Setchell (1978). In the testis, testosterone is synthesized from pregnenolone through two major pathways, the so called 4-ene and 5-ene pathways, and in the boar evidence suggests that the 5-ene pathway is particularly important (see Figure 2.1). Baulieu, Fabre-Jung and Huis in't Veld (1967) found larger quantities of DHA sulphate and testosterone than unconjugated DHA and androstenedione in the testis and spermatic vein blood of the boar, and recently Setchell et al. (personal communication) confirmed these findings for spermatic vein blood, and in addition found even higher concentrations of steroid, particularly DHA sulphate, in testicular lymph. Raeside and Howells (1971) also isolated 5. androstenediol (5-androstene-3 $\beta, 17 \beta$-diol) sulphate from spermatic vein blood. Ruokonen and Vihko (1974) provided a detailed account of steroid 


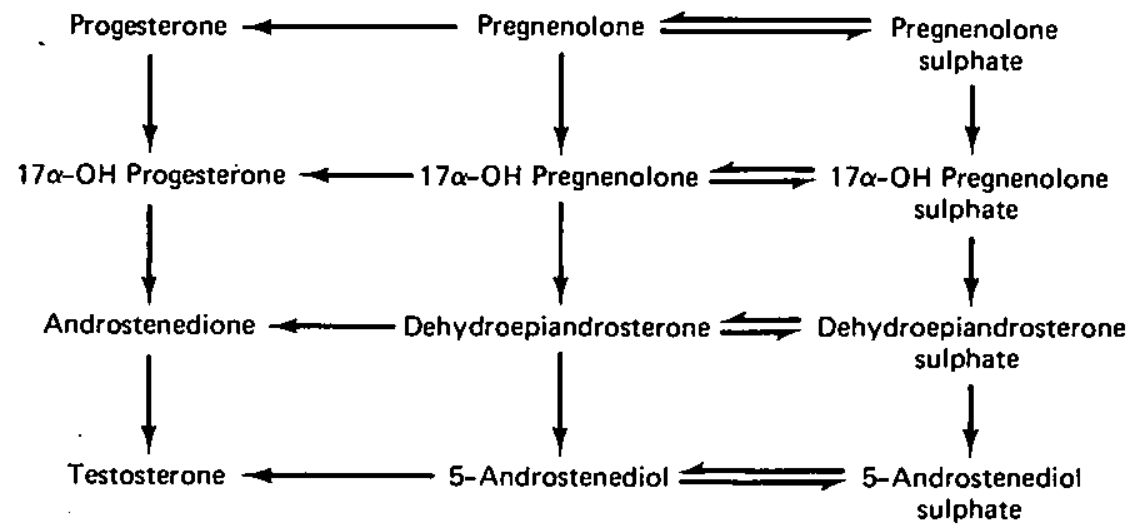

Figure 2.1 Biosynthesis of androgens from $C_{21}$ steroids in boar testis.

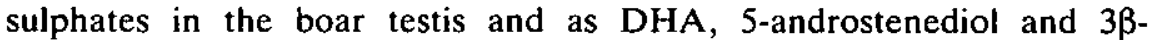
androstanediol $\left(5 \alpha\right.$-androstane-3 $\beta, 17 \beta$-diol) were the main $\mathrm{C}_{19}$ steroids present as monosulphates, speculated that the 5-ene pathway for testosterone synthesis was probably important in the boar. Furthermore the preponderance of steroid sulphates suggested that these might act as intermediates or regulators of testosterone synthesis (Roberts et al., 1964; Notation and Ungar, 1969; Payne and Jaffe, 1970). Booth (1975) also found that DHA and 5-androstenediol (free and sulphated) were quantitatively more important than testosterone or androstenedione in boar testicular extracts and particularly in those of mature animals (see Figure 2.2). A similar pattern for androgens was also found in the testicular tissue of intersex pigs (Booth and Polge, 1976). Previous speculation concerning

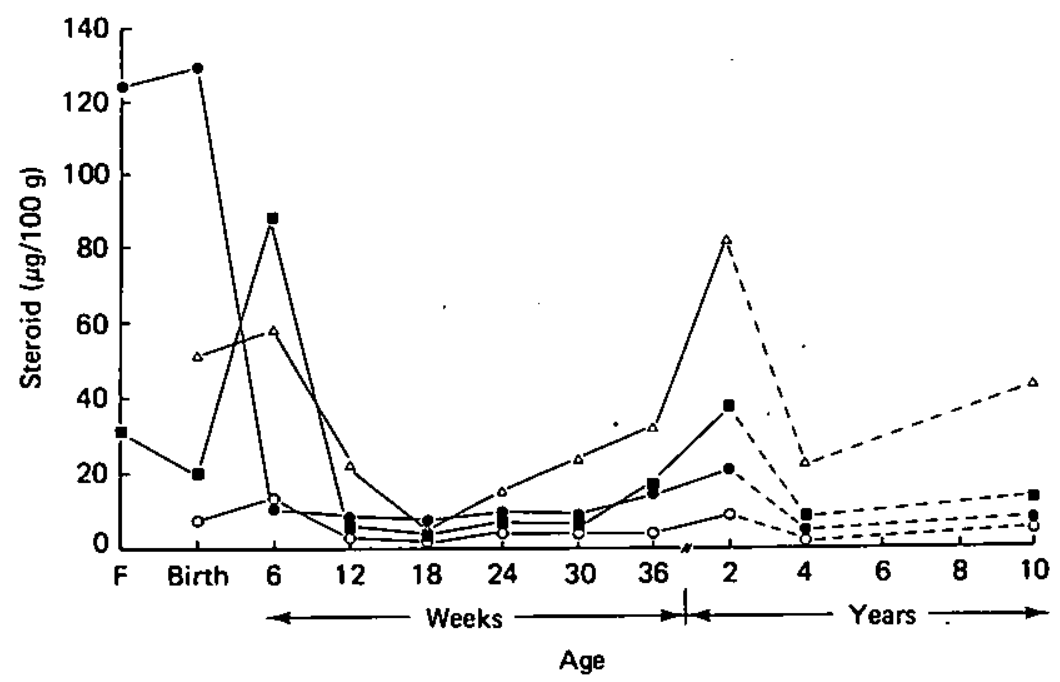

Figure 2.2 Age-related changes in the concentration of unconjugated androgens in boar testis. Values between 84 days gestation $(F)$ and two years are means, values for individual boars older than two years are related by a broken line. $O$ testosterone; $O$ androstenedione; DHA; $\triangle$ 5-androstenediol. From Booth (1975) 
the role of sulphated androgen intermediates in testosterone synthesis was substantiated when Ruokonen (1978) incubated minces of boar testis with both unlabelled and radioactively labelled DHA sulphate; 5androstenediol sulphate was the main metabolite, but free 5androstenediol, testosterone and androstenedione were also formed. Related to this was the finding that $3 \beta$-hydroxy,5-ene steroid sulphates were formed from pregnenolone sulphate with the sulphate moiety remaining intact (Gasparini, Hochberg and Lieberman, 1976). A key enzyme in steroid-producing tissues converting 5-ene to 4-ene steroids is $3 \beta$ hydroxy,5-ene steroid dehydrogenase (4-ene/5-ene isomerase). Dufour and Raeside (1968) demonstrated histochemically the presence of this enzyme in mature boar testis with free DHA and 5-androstenediol as substrates. Testosterone 5 -androstenediol and oestradiol-17 $\beta$ were suitable substrates for the histochemical demonstration of $17 \beta$-hydroxysteroid dehydrogenase in boar testis, and these studies were extended to foetal pigs (Moon and Raeside, 1972). More detailed studies have been carried out on steroid interconversions in various preparations of boar testis. Inano and Tamaoki (1975) studied the cofactor requirements for the interconversion of androstenedione and testosterone by $17 \beta$ hydroxysteroid dehydrogenase, which is distributed evenly between agranular and granular microsomes (Cooke and Gower, 1977), and Shimizu (1978) found that pregnenolone was converted by the microsomal fraction to 5 -androstene- $3 \beta, 17 \alpha$-diol.

Testosterone is the predominant androgen in the testis of the foetal pig (Segal and Raeside, 1975; Booth, 1975; see Figure 2.2), and significant fluctuations in its occurrence are found during foetal life. Testosterone production by the foetal testis is elaborated at the time of sexual differentiation of the gonad (day 26 onwards) (Pelliniemi, 1976) as indicated by the levels of steroid in the testis (Raeside and Sigman, 1975), in vitro production by the testis (Stewart and Raeside, 1976), levels in the umbilical artery and amniotic fluid (Ford, Christenson and Maurer, 1980) and amounts in peripheral serum (Colenbrander, de Jong and Wensing, 1978). By the time sexual differentiation of the genital system has been initiated (day 40) there is a fall in testosterone production until about 100 days of gestation, when levels in the testis (Segal and Raeside, 1975) and plasma (Colenbrander, de Jong and Wensing, 1978) increase to term. After parturition there is wide individual variation in the production of testosterone and androstenedione (Hoffmann, Claus and Karg, 1970; Gray et al. 1971; Elsaesser, Konig and Smidt, 1972), which has been confirmed and extended to other steroids by Booth (1975). However despite this, patterns of steroid production are apparent between birth and maturity. Steroid determinations on the testis (Elsaesser, Konig and Smidt, 1972; Booth, 1975) and peripheral blood (Elsaesser et al., 1976; Colenbrander, de Jong and Wensing, 1978; Tan and Raeside, 1980) have shown that relatively high levels of androgen are present during the postnatal period (see Figure 2.2), decreasing during early puberty before increasing again between late puberty and maturity. In the peripheral blood of the adult boar, testosterone is usually $>2 \mathrm{ng} / \mathrm{ml}$. However much higher levels of DHA sulphate, 16-175 ng/ml, (Booth, 1980a; Tan and Raeside, 1980; Setchell et al., personal communication) and 5-androstenediol sulphate (Booth, 1980a) are present. 
Ford and Schanbacher (1977) found elevated levels of plasma luteinizing hormone ( $\mathrm{LH})$ during the first three weeks of postnatal life, but in other studies age-related changes in androgen production were not paralleled by similar changes in LH secretion (Elsaesser et al., 1976; Lapwood and Florcruz, 1978), although during puberty LH showed a highly pulsatile mode of secretion. Reports of a diurnal variation in androgen secretion are contradictory. The data of Claus and Gimenez (1977) and Claus and Hoffmann (1980), indicate that the highest levels of testosterone in spermatic vein and peripheral plasma occur during the afternoon and after midnight. However, Sanford et al. (1976) and Lapwood and. Florcruz (1978) did not find a diurnal variation in either testosterone or LH secretion at any age; the latter workers stress that the contradictory findings in relation to a diurnal variation in hormone secretion may be due to differences in controlling for environmental factors such as light and stress. This aspect has been studied to some extent by Liptrap and Raeside (1975) and Pitzel et al. (1980). These investigators have shown that in both Yorkshire boars and miniature pigs respectively, the administration of either corticosteroids or ACTH caused a rise in plasma testosterone (60-90 minutes post injection) which is followed by a decrease (6-12 hours post injection). No diurnal variation was found for testosterone following ACTH, but marked diurnal changes were still found for corticosteroids (Pitzel et al., 1980). It is postulated that the gradual decrease in LH after ACTH treatment is due to the negative feedback of the initial increase in testosterone; however the way corticosteroids influence testosterone secretion is not known. Ellendorff et al. (1975) and Liptrap and Raeside (1978) have shown that copulation results in an increase in plasma testosterone, and the continued presence of an oestrous pig or exposure to an aggressive boar leads to similar endocrine changes. Since Liptrap and Raeside (1978) found plasma corticosteroids increased rapidly before testosterone levels rose after exposure of their boars to other pigs, this adds further support for a role of corticosteroids in mediating testosterone release in certain behavioural situations.

Elsaesser et al. (1976) have measured $5 \alpha$-dihydrotestosterone and progesterone in the peripheral plasma of miniature boars; progesterone is mainly testicular in origin since castration lowers the plasma concentration. The plasma levels of $5 \alpha$-dihydrotestosterone are a fifth to a tenth that of testosterone, and although the Leydig cells could be a direct source of $5 \alpha$-dihydrotestosterone (Morat and Courty, 1979), extragonadal sources are possible as is the case in the male rabbit (Booth and Jones, 1980).

\section{Oestrogens}

\section{TESTICULAR PRODUCTION}

Among the earliest evidence for oestrogens in the boar was the determination of large amounts of these steroids in urine (see review by Velle, 1966) with oestrone as the predominant oestrogen, followed by oestradiol and oestriol (Busch and Ittrich, 1968; see also Table 2.1). The testis seems to be the major source of oestrogens, since oestrone and oestradiol-17 $\beta$ have been isolated from the testis (Velle, 1958a), castration results in a marked 
fall in urinary oestrogens, and gonadotrophin stimulation causes a significant increase in urinary oestrogen excretion (Lunaas and Velle, 1965; Raeside, 1965). Oestrogen excretion is similar to androgen excretion in so far as it shows wide individual variation (Velle, 1958b), and considerable daily variation (Raeside, 1965).

The pathways for the biosynthesis of oestrogen in the boar testis have not been elucidated, but it is likely that androstenedione and testosterone are obligatory intermediates (Engel, 1973). Furthermore since DHA and its sulphate are precursors of oestrogen in those tissues capable of converting 5-ene $\mathrm{C}_{19}$ steroids to 4-ene $\mathrm{C}_{19}$ steroids (Andersen and Lieberman, 1980), the boar testis would appear to be well equipped for oestrogen synthesis.

Recently oestrogens have been measured in peripheral plasma, spermatic vein blood, testicular lymph and rete testis fluid of boars (see Table 2.1 ). In keeping with earlier findings for oestrogen in urine, oestrone is the

Table 2.1 COMPOSITE DATA ON THE OCCURRENCE OF OESTROGENS IN THE ADULT BOAR

\begin{tabular}{|c|c|c|c|c|c|}
\hline & $\begin{array}{l}\text { Urine } \\
(\mathrm{mg} / 24 \mathrm{~h})\end{array}$ & $\begin{array}{l}\text { Peripheral } \\
\text { blood } \\
(\mathrm{ng} / \mathrm{ml})\end{array}$ & $\begin{array}{l}\text { Spermatic } \\
\text { vein blood } \\
(\mathrm{ng} / \mathrm{ml})\end{array}$ & $\begin{array}{l}\text { Testicular } \\
\text { lymph } \\
(\mathrm{ng} / \mathrm{ml})\end{array}$ & $\begin{array}{l}\text { Rete restis } \\
\text { fluid } \\
(\mathrm{ng} / \mathrm{ml})\end{array}$ \\
\hline \multicolumn{6}{|c|}{ Unconjugated oestrogens: } \\
\hline Total & & $\left\{\begin{array}{l}0.06-0.25^{(\mathrm{c})} \\
0.06^{(\mathrm{c})} \\
0.04-0.53^{(\mathrm{d})}\end{array}\right.$ & $\begin{array}{l}0.08-2.37^{(c)} \\
0.30^{(c)}\end{array}$ & $0.05^{(c)}$ & $0.08^{(e)}$ \\
\hline $\begin{array}{l}\text { Oestrone } \\
\text { Oestradiol }\end{array}$ & & $\begin{array}{l}0.07^{(d)} \\
0.03^{(d)}\end{array}$ & & & \\
\hline \multicolumn{6}{|c|}{ Conjugated oestrogens: } \\
\hline Total & & $\left\{\begin{array}{l}0.75-4.00^{(\mathrm{c})} \\
10.1^{(\mathrm{c})} \\
8.41-198^{(\mathrm{d})}\end{array}\right.$ & $\begin{array}{l}0.78-7.58^{(\mathrm{c})} \\
29.2^{(\mathrm{c})}\end{array}$ & $284^{(c)}$ & $2.45^{(c)}$ \\
\hline $\begin{array}{l}\text { Ocstrone } \\
\text { Oestradiol }\end{array}$ & $\begin{array}{l}1.10-26.8^{(t)} \\
0.11-5.29^{(n)}\end{array}$ & $\begin{array}{l}20.1^{(d)} \\
8.50^{(d)}\end{array}$ & & & \\
\hline
\end{tabular}

Data taken from the following sources:

(a) Racside (1965);

(b) Velle (1976);

(c)Claus and Hoffmann (1980):

(d) Booth (1980):

(c) Setchell et al. (personal communication).

predominant oestrogen in plasma, particularly as the sulphate. It is noteworthy that unconjugated oestrogen in boar plasma is higher than that in the plasma of oestrous gilts (Henricks, Guthrie and Handlin, 1972). The results of Booth (1980a) indicate that some of the oestrogen in boar plasma may originate from peripheral aromatization of androgens, since higher levels of both unconjugated and sulphate conjugated oestrogen were found in the plasma of castrated boars receiving testosterone and 5androstenediol, than in controls receiving oil only. Claus and Hoffmann (1980) found that plasma oestrogens increased from puberty to maturity, and in response to HCG; conjugated oestrogen also showed a diurnal variation similar to testosterone. 


\section{Target organ responses to androgens and oestrogens}

The testis is both a producer and target organ for steroids. Androgens produced primarily in the Leydig cells play a vital role in supporting spermatogenesis (Setchell, 1978). Richards and Neville (1973) found that the seminiferous tubules of the rat converted DHA to 5-androstenediol and this may occur in the boar, since the highest levels of 5-androstenediol in relation to DHA are found in the boar testis after the onset of spermatogenesis (see Figure 2.2). In the rat testis, oestrogen may be directly involved in the regulation of androgen synthesis.in addition to an indirect negative feedback effect on pituitary LH secretion (Ford and Schanbacher, 1977; Kalla et al., 1980). Similarly, the high oestrogen levels in boar testis, particularly in the lymph (see Table 2.l) may also have a local effect in the gonad, modulating its potential to produce equally large quantities of $\mathrm{C}_{19}$ steroid.

In studies involving the administration of oestrogen to intact boars, it is not clear whether the effects on androgen production are direct, or through the modulation of LH release. Echternkamp et al. (1969) found that $96 \mathrm{mg}$ of diethylstilboestrol implanted into young boars had no significant effect on plasma androgen activity or on the weight of the testes and seminal vesicles, but the weight of the prostate and boar odour were reduced. Schilling and Lafrenz (1977) found injections of 5 and $10 \mathrm{mg}$ oestradiol valerionate to boar piglets on days 8 and 25 of life, increased plasma androgen levels and the development of interstitial tissue when the pigs were 5 months old; however degenerative changes were present in the spermatogenic epithelium, in keeping with known deleterious effects of exogenous oestrogen on the testis (Kaur and Mangat, 1980). Some of these findings are difficult to interpret, the more so since different oestrogens, treatment regimes, age of animal and physiological indices were investigated. This aspect is reinforced in studies on the castrated boar aimed at elucidating the role of androgens and oestrogens on accessory organ function and sexual behaviour. Joshi and Raeside (1973) castrated boars around 12 months of age which had been trained to mount a dummy, and then gave them a series of intramuscular injections for 6-week periods of testosterone alone, or alternating with diethylstilboestrol, oestrone or oestradiol-17 $\beta$ in combination with testosterone. Whereas testosterone alone had only a slight effect on restoring the volume of ejaculates and libido, oestrogen in combination with testosterone significantly enhanced both the secretory activity of the accessory organs and libido; these findings indicated a synergistic role for oestrogens with androgens. On the other hand, Booth (1980a) did not find a synergistic effect of oestrone with androgens on the development of accessory organs in castrated boars (Table 2.2). Since the ratio between androgen and oestrogen, and the total dose of steroid were similar to that used by Joshi and Raeside (1973), one explanation for a certain lack of agreement between the two studies could be the gross difference in the age of castration before steroid treatment. Perhaps therefore the boar is somewhat refractory to oestrogen (Linde, Einarsson and Gustafsson, 1975), or alternatively the fact that most of the circulating oestrogen is sulphated could mean that the steroid is in a relatively inactive form. However preliminary results from a study in 
progress indicate that the prostate and seminal vesicles of the boar have the capacity to convert ${ }^{3} \mathrm{H}$-labelled oestrone sulphate in vitro to free oestrone and oestradiol-17 $\beta$. One of the aims of the investigation by Booth (1980a) and a subsequent unpublished study using $1 \mathrm{mg} / 5 \mathrm{~kg} 5$-androstenediol, was achieved by the demonstration that this steroid has significant androgenic activity in the boar, particularly with regard to stimulating the seminal vesicles (Table 2.2). This finding is supported by recent findings in the author's laboratory showing that the prostate and seminal vesicles have the capacity in vitro to convert ${ }^{3} \mathrm{H}$-labelled 5 -androstenediol to testosterone, $5 \alpha$-dihydrotestosterone and $5 \alpha$-androstanediols.

Table 2.2 RESPONSE OF ACCESSORY ORGANS (AT 38 WEEKS OF AGE) IN BOARS CASTRATED PREPUBERTALLY AND RECEIVING TWICE WEEKLY INJECTIONS OF STEROIDS IN OIL BETWEEN 14 AND 38 WEEKS OF AGE

\begin{tabular}{|c|c|c|c|c|c|c|}
\hline \multirow{2}{*}{$\begin{array}{l}\text { Steroid } \\
\text { treatments }\end{array}$} & \multirow{2}{*}{$\begin{array}{l}\text { No. of } \\
\text { pigs }\end{array}$} & \multicolumn{3}{|c|}{ Gland weights $(\mathrm{g})$} & \multicolumn{2}{|c|}{ Seminal vesicles } \\
\hline & & Prostate & $\begin{array}{l}\text { Seminal } \\
\text { vesicle }\end{array}$ & $\begin{array}{l}\text { Bulbo- } \\
\text { urethral }\end{array}$ & $\begin{array}{l}\text { Fructose } \\
\text { (mg) }\end{array}$ & $\begin{array}{l}\text { Zinc } \\
(\mathrm{mg})\end{array}$ \\
\hline $\begin{array}{l}\text { A } \\
B \\
C \\
D \\
E \\
F\end{array}$ & $\begin{array}{l}3 \\
3 \\
3 \\
3 \\
3 \\
4\end{array}$ & $\begin{array}{l}9.20 \pm 2.62^{*} \\
5.40 \pm 0.57 \\
7.17 \pm 1.37 \\
4.20 \pm 1.50^{*} \\
0.56 \pm 0.03 \\
11.8 \pm 1.27\end{array}$ & $\begin{array}{l}38.0 \pm 5.59 \\
32.8 \pm 3.43 \\
28.9 \pm 3.31 \\
64.2 \pm 8.86 \dagger \\
0.94 \pm 0.11 \\
211 \pm 5.51\end{array}$ & $\begin{array}{l}70.9 \pm 10.9 \\
49.0 \pm 4.86 \\
56.9 \pm 5.63 \\
40.7 \pm 7.10 \\
5.29 \pm 0.14 \\
122 \pm 2.60\end{array}$ & $\begin{array}{l}62.5 \pm 24.3 \\
34.1 \pm 12.7 \\
46.7 \pm 31.2 \\
104 \pm 40.7 \\
0.053 \pm 0.017 \\
69.4 \pm 23.0\end{array}$ & $\begin{array}{l}5.55 \pm 1.32 \\
6.13 \pm 1.20 \\
2.69 \pm 0.57 \\
17.7 \pm 1.54 \dagger \\
0.035 \pm 0.005 \\
60.5 \pm 11.3\end{array}$ \\
\hline
\end{tabular}

Steroid treatments: A, testosterone $(2 \mathrm{mg} / 5 \mathrm{~kg})+$ oestrone $(1 \mathrm{mg} / 5 \mathrm{~kg}) ; \mathrm{B} .5$-androstenediol $(2 \mathrm{mg} / 5 \mathrm{~kg})+$ oestrone $(1 \mathrm{mg} / 5 \mathrm{~kg}) ; \mathrm{C}$, testosterone $(2 \mathrm{mg} / 5 \mathrm{~kg}) ; \mathrm{D}, 5$-androstencdiol $(2 \mathrm{mg} / 5 \mathrm{~kg}) ; \mathrm{E}$, untreated castrated pigs; $\mathbf{F}$, untreatcd intact boars.

Data expressed as the mean \pm S.E.M.

-Significantly different from each other, $P<0.05$.

$\dagger$ Significantly different from treatments $A-C, P<0.05$.

From Booth (1980a)

Since DHA and 5-androstenediol sulphates are major steroids in boar plasma, studies on the fate of these conjugates are particularly important for a greater understanding of androgen action in the male pig. In this regard Joshi (1971) found that DHA sulphate supplements the effect of testosterone on accessory organs, and preliminary evidence (Booth, unpublished) has been obtained for the conversion of ${ }^{3} \mathrm{H}$-labelled DHA and 5 -androstenediol sulphates to the corresponding free steroids in in vitro incubations with minces of the prostate and seminal vesicles. Since androgens and oestrogens are present in testicular fluid (Setchell et al., personal communication) it remains to be demonstrated what effects these might have on the epididymis.

There is a sexual dimorphism in the submaxillary salivary gland of the pig (Booth, Hay and Dott, 1973), and indirect evidence indicates that testicular steroids are involved. Booth (1977) demonstrated in vitro that the submaxillary gland of the boar responds like a typical androgen target organ by converting testosterone to $5 \alpha$-dihydrotestosterone and $5 \alpha$ androstanediols. Furthermore, $5 \alpha$-dihydrotestosterone is present in greater amounts than testosterone in the submaxillary glands of boars, but not 
in female pigs (Booth, 1972). Flood (1973) and Booth, Hay and Dott (1973) showed histochemically that pig submaxillary glands contain steroid metabolizing enzymes, but the latter workers using DHA as substrate, also showed that the activity of $3 \beta$-hydroxy-5-ene steroid dehydrogenase was greatest in the serous cells of boar glands. The finding that free DHA and 5 -androstenediol are converted to testosterone and $5 \alpha$-reduced steroids in the submaxillary gland of the boar, suggests that these steroids may act as prohormones adding to the total androgen output of the testis. The sexual dimorphism in the submaxillary gland of the pig seems to be related to the accumulation of the musk-smelling 16-androstenes in the gland of the boar, and their release into saliva as pheromones (Booth, 1980b).

Joshi and Raeside (1973) found that oestrogen enhanced the effect of testosterone on libido in castrated boars. This finding agrees with the concept that the effects of aromatizable androgens on sexual behaviour are mediated by oestrogens (Callard, Petro and Ryan, 1978). On the other hand oestrogen alone induces female sexual behaviour in castrated pigs (Ford and Schanbacher, 1977), thus indicating that $5 \alpha$-reduction of testosterone is also required for the expression of male behaviour in the pig as in sheep (Parrott, 1978). It is noteworthy that 5-androstenediol did not support copulatory behaviour in castrated boars as well as testosterone (Booth, 1980a), a finding in keeping with studies in the rat (Morali et al., 1974) and one explanation for this is that only some of the 5-androstenediol is converted to testosterone for aromatization. Other effects of testicular steroids at the cerebral level in the boar, have been studied by Parvizi et al. (1977) who showed that implants of $5 \alpha$-dihydrotestosterone, testosterone and other steroids into the mediobasal hypothalamus or amygdala, affected both the stimulatory and inhibitory mechanisms of LH release.

Much of the work on the anabolic effects of androgens and oestrogens in the pig have involved the use of synthetic steroids, whereupon it has been demonstrated that oestrogens have a pronounced growth-promoting effect which is enhanced by androgen (Fowler, 1976). However, the use of synthetic steroids leads to concern over their possible effects on human health, since they may accumulate in the carcasses. Until convenient methods are available for monitoring levels of synthetic steroids in carcasses (Kroes et al., 1976), it has been suggested that the use of naturally occurring steroids as anabolic agents might overcome the problem of depot effects (Velle, 1976). Rossouw, Skinner and Kemm (1971) injected pigs from weaning to porker weight with androstenedione and observed a growth-promoting effect of the steroid. The effect was greatest in intact boars, suggesting other testicular steroids were involved. In a recent study by the author, castrated boars received subcutaneous injections of 5-androstenediol $(1 \mathrm{mg} / \mathrm{kg}$, twice weekly) from 12-40 weeks of age. The pigs were slaughtered at 40 weeks of age, and the Meat and Livestock Commission carried out a detailed carcass evaluation. As found in a previous study (see Table 2.2), 5-androstenediol had a pronounced androgenic effect on the accessory organs, but no statistically significant anabolic effects were found. There was, however, a trend for some carcass characteristics of the steroid-treated pigs to be intermediate between those of intact and castrated boars (see Figure 2.3 and Table 2.3). Further studies of this nature are needed involving larger groups of animals. 


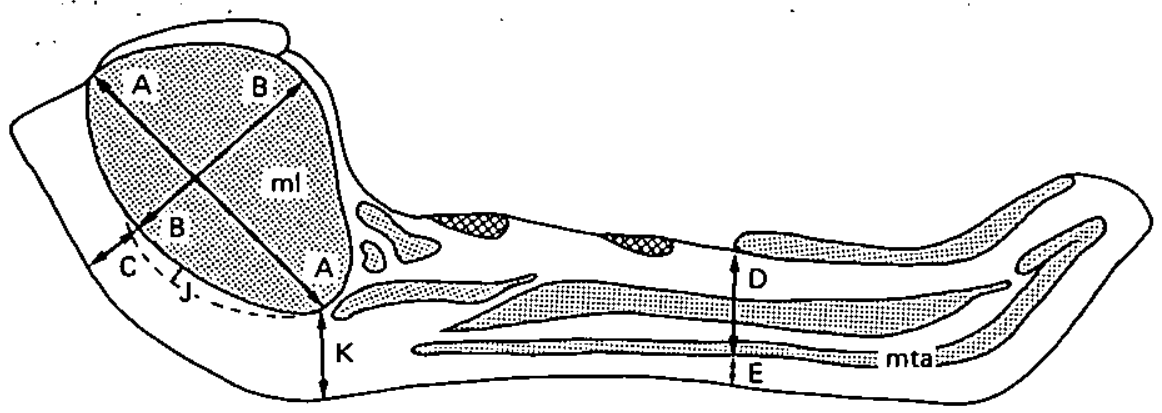

Figure 2.3 A possible anabolic role for 5-androstenediol in the boar. Measurements were taken on the cut surface of the forequarter at the head of the last rib. Values (given in Table 2.3) are the means for five castrated boars receiving 5 -androstenediol $(1 \mathrm{mg} / \mathrm{kg})$ between 12 and 40 weeks of age, and five castrated boars and three intact boars receiving oil injections only. Although there were no statistically significant differences between the groups, there was a trend towards greater leanness in the intact boars, and to a lesser extent in steroid-treated pigs compared with untreated controls. $\mathrm{ml}$-muscle longissimus, mta-muscle transversus abdominis. (Booth unpublished, the author is grateful for the carcass analyses carried out by the Meat and Livestock Commission).

Table 2.3 RELATIVE DISTRIBUTION OF MUSCLE AND FAT ON CUT SURFACE OF FORE-QUARTER AT THE HEAD OF THE LAST RIB IN INTACT BOARS, CASTRATED BOARS AND CASTRATED BOARS TREATED WITH $5 \alpha-$ ANDROSTENEDIOL

\begin{tabular}{lccc}
\hline Measurements $^{(\mathfrak{a})}$ & $\begin{array}{l}\text { Intact boar } \\
(\mathrm{mm})\end{array}$ & $\begin{array}{l}\text { Castrate }+5 \alpha \text {-Androstenediol } \\
(\mathrm{mm})\end{array}$ & $\begin{array}{l}\text { Castrate } \\
(\mathrm{mm})\end{array}$ \\
\hline A & 92.0 & 89.8 & 90.8 \\
B & 56.0 & 52.6 & 51.6 \\
C & 18.0 & 19.4 & 20.2 \\
D & 26.3 & 25.4 & 23.0 \\
E & 8.33 & 9.60 & 10.0 \\
J & 4.67 & 4.60 & 6.00 \\
K & 25.7 & 24.8 & 26.8 \\
\hline
\end{tabular}

(a) For definition of A-K see Figure 2.3.

\section{6-Androstenes}

\section{TESTICULAR PRODUCTION}

The 16-androstenes are quantitatively probably the most abundant steroids produced by the pig testes (Prelog and Ruzicka, 1944; Claus, 1970; Ruokonen and Vihko, 1974; Booth, 1975; Booth and Polge, 1976; see Table 2.4). It was generally assumed that these musk-smelling steroids occurred in only a few species such as the pig and man as metabolites of androgens. However, a series of investigations by Gower and co-workers (see review by Gower, 1972) indicated that androgens are unlikely to be significant precursors of 16-androstenes in pig testes. Gower and Ahmad (1967) showed in vitro that boar testes convert pregnenolone to give high yields of $3 \beta$-androstenol $(10-15 \%)$ and some $3 \alpha$-androstenol $(1-2 \%)$. 


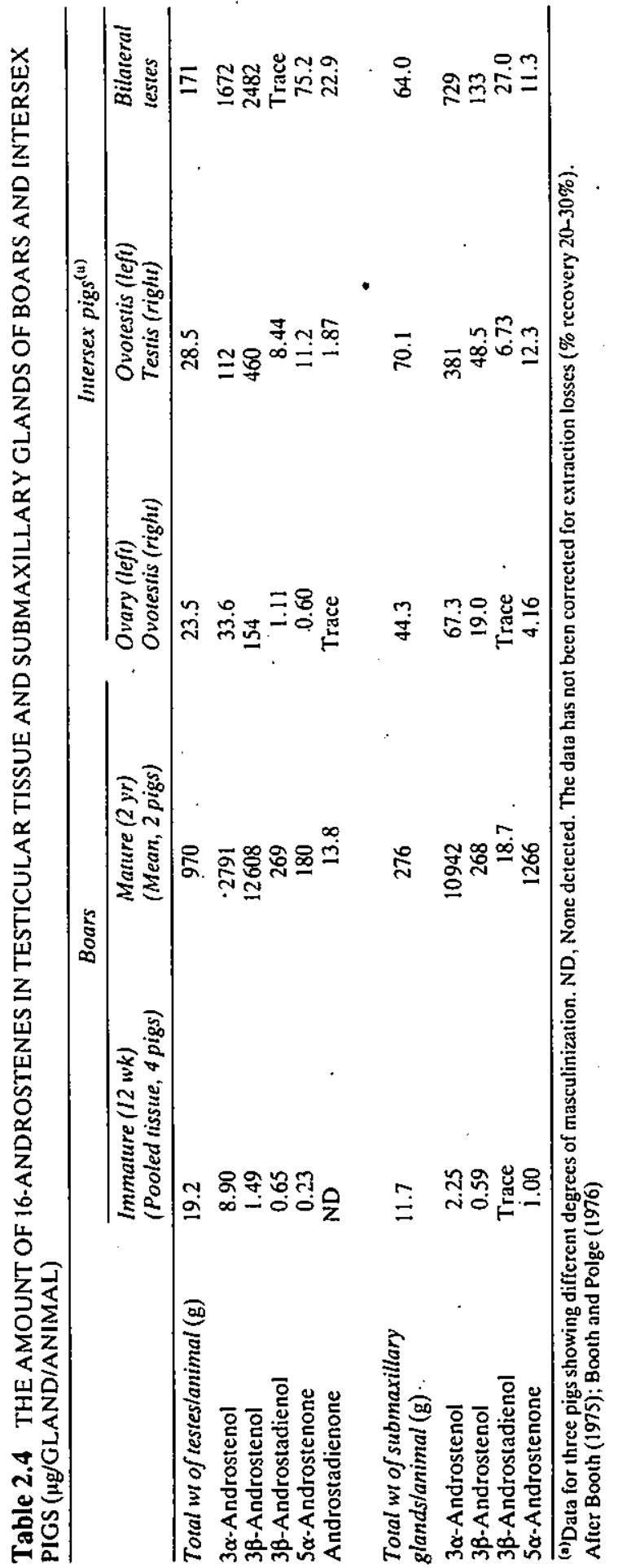


Progesterone also acts as a substrate (Ahmad and Gower, 1968) but not $17 \beta$-hydroxyprogesterone, DHA, testosterone, testosterone acetate or 16-dehydroprogesterone, indicating that 16-androstenes are formed from $\mathrm{C}_{21}$ steroid precursors before $17 \beta$-hydroxylation and side-chain cleavage (see Figure 2.4). Subsequently, Katkov and Gower (1970) and Brophy and Gower (1972) showed that $3 \beta$-androstadienol (5,16-androstadien-3 $\beta$-ol) and androstadienone $(4,16$-androstadien-3-one) are important intermediates between pregnenolone and $5 \alpha$-reduced 16-androstenes. The enzyme

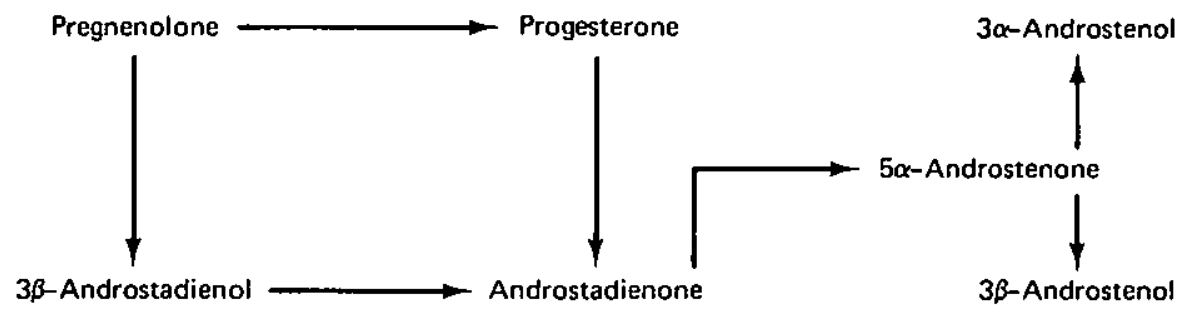

Figure 2.4 Biosynthesis of 16-androstenes from $C_{21}$ steroids in boar testis.

system responsible for the conversion of pregnenolone to $3 \beta$ androstadienol is referred to as 'andien- $\beta$ synthetase'; however the steps between pregnenolone and $3 \beta$-androstadienol have not been defined. Andien- $\beta$ synthetase resides in the microsomal fraction of the testes (Gower and Loke, 1971; Shimizu and Nakada, 1976), and predominantly $(66 \%)$ in the agranular components (Cooke and Gower, 1977). Mason, Park and Boyd (1979) using a microsomal preparation from immature pig testes in incubations with ${ }^{14} \mathrm{C}$-labelled pregnenolone, found $3 \beta$ hydroxypregn-5,16-dien-3-one in addition to $3 \beta$-androstadienol and $17 \alpha$ hydroxypregnenolone and concluded that this $C_{21}$ steroid might be an intermediate in 16-androstene synthesis, at least in young pigs.

After an infusion of ${ }^{3} \mathrm{H}$-labelled pregnenolone into the spermatic artery of a mature boar, Saat et al. (1972) found radioactively labelled $3 \alpha /$ $3 \beta$-androstenols, primarily as sulphates, in the testes and spermatic vein blood. Ruokonen and Vihko (1974) also isolated these steroid sulphates from boar testes. Recently sulpho-conjugation of $3 \beta$-androstenol has been found in porcine liver (Fish, Cooke and Gower, 1980), but $3 \beta$-androstenol predominates as the glucuronide in urine (Gower, Harrison and Heap, 1970).

Claus, Hoffmann and Karg (1971) using gas-liquid chromatography showed that both the major boar taint steroid $5 \alpha$-androstenone ( $5 \alpha-$ androst-16-en-3-one) and testosterone in blood plasma of boars increased with age and the amounts of $5 \alpha$-androstenone $(6.0-22.3 \mathrm{ng} / \mathrm{ml})$ were greater than those in females $(0.8-2.0 \mathrm{ng} / \mathrm{ml})$ or castrated boars $(1.3-2.7$ $\mathrm{ng} / \mathrm{ml}$ ). Similar results for $5 \alpha$-androstenone were obtained by Andresen (1974) and Claus and Hoffmann (1980) using a radioimmunoassay; however a diurnal variation was found by Claus and Gimenez (1977) and Claus and Hoffmann (1980), but not by Andresen (1975a). Andresen (1975a), Carlstrom et al. (1975) and Claus and Hoffmann (1980) found a biphasic 
increase in plasma $5 \alpha$-androstenone after HCG treatment; the first peak was reached within 3 hours, and the second larger peak by $28-30$ hours. Similar levels of unconjugated $3 \alpha$-androstenol to unstimulated $5 \alpha$ androstenone were measured in boar plasma (Bicknell and Gower, 1976), but lower levels $(0.24-0.77 \mathrm{ng} / \mathrm{ml})$ of the steroid alcohol compared with the ketone were found in the plasma of female and castrated pigs.

\section{ACCUMULATION IN PERIPHERAL TISSUES}

The presence of 16-androstenes in peripheral tissues of the pig is of interest for two main reasons. First, these compounds are among the few mammalian pheromones identified chemically, and this has therefore resulted in a greater interest in studies on olfaction in the pig (see reviews by Claus, 1979; Booth, 1980b). Secondly man's olfactory sense is sensitive to these compounds (Kloek, 1961) and many people dislike their odour, particularly when associated with pig meat (boar taint).

Patterson (1968a) isolated $3 \alpha$-androstenol from the submaxillary glands of boars, but not male castrates or females. This finding was confirmed in more extensive studies by Booth (cited by Gower, 1972), Katkov, Booth and Gower (1972) and Booth (1975), (see also Table 2.4). High concentrations of 16-androstenes were also found in the submaxillary glands of intersex pigs (Booth and Polge, 1976; and Table 2.4). Although there are reports that 16-androstenes are present in the parotid glands of boars (Claus, 1970; Claus, Hoffmann and Karg, 1971), it seems that the submaxillary gland is primarily involved in concentrating these odorous steroids (Patterson, 1968a; Katkov, Booth and Gower, 1972). Furthermore, recent work in the author's laboratory, using polyacrylamide gel

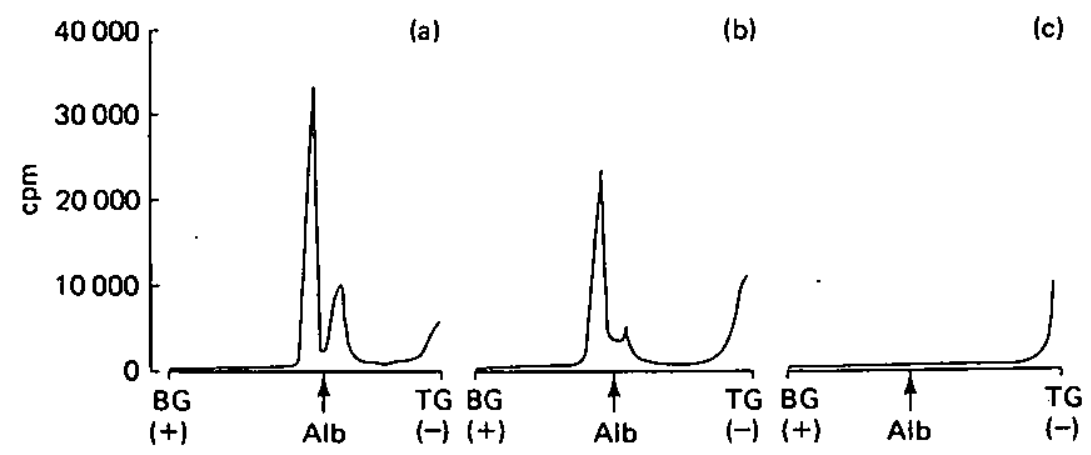

Figure 2.5 Binding of $\left(5 \alpha, 6 \alpha_{-}{ }^{3} \mathrm{H}\right) 5 \alpha$-androstenone (cpm) (Isocommerz, Dresden) to high molecular weight components in salivary gland cytosols and saliva of mature boar. Samples $(80 \mu \mathrm{l})$ of 1 in 20 dilution of submaxillary gland (a) and parotid gland (c) cytosols prepared in a $10 \mathrm{mM}$ Tris based buffer containing $1 \%$ propanediol, and 1 in 10 dilution of mixed saliva (b) were incubated overnight at $4{ }^{\circ} \mathrm{C}$ with ${ }^{3} \mathrm{H}$-labelled $5 \alpha$-androstenone and run on $7 \%$ polyacrylamide slab gel electrophoresis essentially after Davis (1964). Gel slices (2 mm) were immersed in a toluene-based scintillation medium overnight before counting. BG, bottom of gel; TG, top of separating gel; Alb., albumin. Protein concentrations in (a) $62 \mu \mathrm{g}$, (b) $20 \mu \mathrm{g}$, (c) $43 \mu \mathrm{g}$. From Booth (unpublished) 
electrophoresis has demonstrated that proteins strongly binding $5 \alpha$ androstenone are present in the saliva and cytosols of porcine submaxillary glands but not of the parotid glands (see Figure 2.5). These findings, and the observation that removal of the submaxillary glands in boars reduces their ability to induce the mating stance in oestrous pigs (Perry et al., 1980 ), is further evidence indicating that the boar submaxillary gland has a special role in eliminating the pheromonal steroids. Since $3 \alpha$-androstenol is the predominant 16-androstene in boar saliva (Booth, 1980b) and submaxillary gland, the binding of this steroid in these media is under investigation. In blood plasma, the amounts of $3 \alpha$-androstenol (Bicknell and Gower, 1976) and 5 $\alpha$-androstenone (Claus and Hoffmann, 1980) are similar, therefore the increased amounts of $3 \alpha$-androstenol relative to $5 \alpha$-androstenone in the submaxillary gland and saliva are probably due to conversion of the ketone to the alcohol by the very active $3 \alpha$ hydroxysteroid dehydrogenase in the salivary gland (Katkov, Booth and Gower, 1972; Booth, 1977). A similar ratio of $3 \alpha$-androstenol to $5 \alpha$ androstenone is found in the apocrine sweat glands of the boar (Stinson and Patterson, 1972), but it is not known if this ratio depends on $3 \alpha$-hydroxysteroid dehydrogenase in the sweat glands.

One practica! consequence of the study of 16 -androstenes as pheromones is the commercial availability of aerosols containing $5 \alpha$ androstenone to facilitate the detection of oestrus in pigs housed in the absence of a boar. This application was established on the basis of the work carried out by Melrose, Reed and Patterson (1971) and Reed, Melrose and Patterson (1974), and reviewed in relation to other aspects of olfaction and reproduction in the pig (Booth, 1980b).

The first isolation of $5 \alpha$-androstenone as the major compound responsible for taint in boar fat, was achieved by Patterson (1968b). Subsequently Claus (1970), and Claus, Hoffmann and Karg (1971) reported that $1.03-7.49 \mu \mathrm{g} / \mathrm{g}$ of $5 \alpha$-androstenone were present in the fat of postpubertal boars and Beery and Sink (1971) also demonstrated the presence of $3 \alpha$-androstenol in boar fat. Kaufman, Ritter and Schubert (1976) obtained similar values to Claus, Hoffmann and Karg (1971) for $5 \alpha$-androstenone in boar fat, and values $<0.1 \mu \mathrm{g} / \mathrm{g}$ in the fat of castrated boars and females. Andresen (1975b) established a radioimmunoassay for $5 \alpha$-androstenone in fat, and confirmed the data of earlier work. Malmfors and Andresen (1975) found that the concentration of $5 \alpha$-androstenone in boar fat was positively correlated $(n=0.51-0.54, P<0.001)$ with the intensity of boar taint determined either by the soldering iron technique (Jarmoluk, Martin and Fredeen, 1970), or heating fat samples to $180^{\circ} \mathrm{C}$. The concentration of $5 \alpha$-androstenone in fat was not related to that in plasma $(n=0.36)$, but after HCG treatment (Malmfors et al., 1976), $5 \alpha$-androstenone increased in both plasma and fat. In a study using more animals, Lundstrom et al. (1978) found high correlations between backfat and plasma levels of $5 \alpha$-androstenone after HCG treatment.

\section{Artificial control of boar taint production}

Since castration not only removes the undesirable taint steroids, but also the main source of anabolic steroids, several approaches have been 
investigated to selectively reduce the production of 16 -androstenes, but maintain the production of anabolic steroids in intact boars.

\section{INHIBITION OF 16-ANDROSTENE SYNTHESIS}

Synthetic compounds such as diethylstilboestrol (Eckternkamp et al., 1969) and 19-norethisterone acetate (Rommel, Otto and Blödow, 1975) when administered to intact boars, reduce boar taint in the carcasses, which is likely to be due to a decrease in 16-androstene synthesis associated with the observed atrophy of Leydig cells. However, as mentioned earlier (p.33), the use of synthetic hormones involves a health risk due to possible depot effects. An important consequence of studies on the biosynthesis of 16-androstenes in boar testes, would be to find substances which selectively inhibit enzymes responsible for their synthesis, without affecting the synthesis of androgens; however this aim has not been achieved. Brophy and Gower (1974) found that $5 \alpha$-pregnane-3,20-dione, and a series of $17 \beta$-derivatives of testosterone (Kaufman and Schubert, 1980) inhibited both 16-androstene and androgen biosynthesis.

\section{IMMUNIZATION}

Specific antibodies can be raised against steroids after they have been conjugated chemically with proteins such as bovine serum albumin, and this phenomenon has permitted the development of radioimmunoassays. As a method for eliminating boar taint, boars were injected repeatedly with $5 \alpha$-androstenone linked to bovine serum albumin (Claus, 1975). The levels of $5 \alpha$-androstenone in fat were reduced in the five boars studied, but limitations such as site and frequency of injection, and age at the start of injections were realized. More boars have since been immunized against $5 \alpha$-androstenone by Patterson (personal communication), and the results are encouraging. In boars slaughtered at $90 \mathrm{~kg}$, the amounts of $5 \alpha$ androstenone were reduced considerably in blood $(46 \%, n=3)$ and fat $(72 \%, n=12)$.

\section{GENETIC SELECTION}

Comments have been made that boar taint is more apparent in some breeds than others e.g. Landrace and Pietrain $>$ Large White. Breeding studies on Landrace pigs (Jonsson and Andresen, 1979; Willeke et al., 1980 ) have shown that 'high' and 'low' lines arise for $5 \alpha$-androstenone and testosterone. As the low line effect seems to be due to a delay in puberty, this could result in an undesirable reduction in anabolic effects.

\section{ENVIRONMENTAL FACTORS}

Claus (1977) reported that between August and January, the natural mating period of the wild boar, higher levels of $5 \alpha$-androstenone were 
present in the fat of domestic boars during their second year of life. Patterson (personal communication) also found the highest levels of $5 \alpha$-androstenone in the fat $(0.62 \mu \mathrm{g} / \mathrm{g})$ of a group of Landrace boars $(87 \mathrm{~kg})$ during the natural mating period, but in other combinations of sex and breed (Large White $\times$ Landrace) $\times$ Large White, the highest levels of $5 \alpha$-androstenone were found outside the natural mating period. In all groups the levels of taint steroid $(\sim 0.5 \mu \mathrm{g} / \mathrm{g})$ indicated that intact boars < $90 \mathrm{~kg}$ can be marketed for meat throughout the year. Evidence from a study by Bonneau and Desmoulin (1980) suggests that social conditions affect the levels of $5 \alpha$-androstenone in boars, with higher amounts in grouped pigs particularly of mixed sexes above $80 \mathrm{~kg}$ when sexual activity would be increased at puberty. Bonneau and Desmoulin (1980) and Patterson (personal communication) found a wide individual variation in $5 \alpha$-androstenone levels $(0.21-2.55 \mu \mathrm{g} / \mathrm{g})$ at $95 \mathrm{~kg}$; perhaps some of this variation was due to dominance hierarchies being established, an aspect needing further investigation.

\section{Taint and boar meat}

A survey carried out by Rhodes (1971) indicated that bacon produced from boars $(108 \mathrm{~kg})$ was as acceptable as bacon from gilts of similar weight, to over 350 people. in 125 households and $<1 \%$ of consumers found boar bacon less acceptable on the basis of odour. A second survey (Rhodes, 1972) involving 419 households consisting of 1560 persons, showed that pork joints from carcasses of 24-week old boars were as acceptable as joints from gilts of the same age.

Most of the results from fundamental studies on testicular steroids in the boar, have been obtained during the time boar meat has been introduced to the British market. Generally the results of the endocrinologist support the finding that immature boars at porker weight are producing minimum quantities of $5 \alpha$-androstenone. However, as the boar matures to over $100 \mathrm{~kg}$, the risk of taint increases with the increased testicular output of 16 -androstenes during puberty. This aspect is of particular concern to countries outside the UK who would like to introduce boar meat, but where traditionally pigs are often slaughtered at heavier weights. The knowledge that intact boars are a desirable source of meat, if the risk of taint could be overcome, has led to the investigation of methods which might be practicable for monitoring taint in individual carcasses at the slaughter house. A suitable method must be quick so as not to interfere with the rapid throughput of modern slaughterhouses, and furthermore must be sensitive and reliable. The soldering iron technique of Jarmoluk, Martin and Fredeen (1970) is quick but subjective, dependent upon the considerable variability in human olfactory acuity. By combining this technique with fat biopsies taken from living pigs (Lundstrom, Malmfors and Hansson, 1973), pigs can be monitored before slaughter. Quantitative assessment of $5 \alpha$-androstenone by radioimmunoassay, although sensitive, is elaborate and time-consuming. Recently, however, Andresen (1979) has investigated the possibility of a rapid radioimmunoassay for $5 \alpha$ androstenone, involving the absorption of fat onto filter paper before 
direct assay without solvent extraction; the practical use of this method is being assessed. Another possible method for assessing boar taint is that based on the findings of Forlund, Lundstrom and Andresen (1980). A positive correlation was found between the size of the bulbourethral glands and $5 \alpha$-androstenone in fat $(n=0.56-0.75)$, but a correlation of only $0.28-0.34$ was found between gland weights and boar taint assessed by the soldering iron method, a finding in keeping with the opinion that boar taint is not entirely due to 16-androsterone steroids. Indeed, Lundstrom et al. (1980) have indicated that skatole and indole in boar carcasses can enhance boar taint above that produced by $5 \alpha$-androstenone alone; this adds a new dimension to the subject of boar taint, which is beyond the scope of this review.

\section{Conclusions}

The essential theme of this review has been to emphasize that the boar testis produces a variety of steroids. Of these, three groups of biologically significant steroids namely androgens, oestrogens and 16-androstenes, have been discussed. Studies on these groups of steroids in the boar have shown that this animal should be ideal for future work aimed at answering some of the questions posed by the endocrinologist e.g. is there a role for steroid sulphates other than simply products for excretion, to what extent do prohormones add to the total effect of androgens and oestrogens in target tissues, and what is the role for oestrogen in the male? Already there is considerable evidence to show that in the boar, there is a synergism between the endocrine function of the testis and the production and release of the pheromonal 16-androstene steroids, and this has led to problems with attempts to artificially dissociate these two functions in relation to boar meat production. However, with the knowledge that the risk of boar taint is minimal in young boars, it seems that the market for boar meat should continue to expand, particularly if immunization against $5 \alpha$ androstenone becomes practicable as a means of ensuring that precocious boars do not have tainted carcasses.

\section{Acknowledgements}

I wish to thank Dr B.P. Setchell and his colleagues and Dr R.L.S. Patterson for allowing me to include some of their unpublished data.

\section{References}

AHMAD, N. and GOWER, D.B. (1968). The biosynthesis of some androst-16enes from $\mathrm{C}_{21}$ and $\mathrm{C}_{19}$ steroids in boar testicular and adrenal tissue. Biochem. J. 108, 233-241

ANDERSEN, N.G. and LIEBERMAN, S. (1980). $\mathrm{C}_{19}$ steroidal precursors of estrogens. Endocrinology 106, 13-18 
ANDRESEN, O. (1974). Development of a radioimmunoassay for $5 \alpha$ androst-16-en-3-one in pig peripheral plasma. Acta Endocr. 76, 377-387 ANDRESEN, O. (1975a). 5 $\alpha$-androstenone in peripheral plasma of pigs, diurnal variation in boars, effects of intravenous $\mathrm{HCG}$ administration and castration. Acta Endocr. 78, 385-391

ANDRESEN. O. (1975b). A radioimmunoassay for $5 \alpha$-androst-16-en-3-one in porcine adipose tissue. Acta Endocr. 79, 619-624

ANDRESEN, O. (1979). A rapid radioimmunological evaluation of the androstenone content in boar fat. Acta vet. scand. 20, 343-350

BAULIEU, E.E., FABRE-JUNG, I. and HUIS IN'T VELD, L.G. (1967). Dehydroepiandrosterone sulfate: a secretory product of the boar testis. Endocrinology $\mathbf{8 1}, 34-38$

BEERY, K.E. and SINK, J.D. (1971). Isolation and identification of $3 \alpha$ hydroxy-5 $\alpha$-androst-16-ene and $5 \alpha$-androst-16-en-3-one from porcine adipose tissue. $J$. Endocr. 51, 223-224

BICKNELL, D.C. and GOWER, D.B. (1976). The development and application of a radioimmunoassay for $5 \alpha$-androst-16-en-3 $\alpha$-o1 in plasma. J. Ster. Biochem. 7, 451-455

BONNEAU, M. and DESMOULIN, B. (1980). Evolution de la teneur en androstenone du tissu adipeux dorsal chez le porc male entier de type Large White: variations selon les conditions d'elevage. Reprod. Nutr. Dev. 20, 1429-1437

BOOTH, W.D. (1972). The occurrence of testosterone and $5 \alpha$ dihydrotestosterone in the submaxillary salivary gland of the boar. $J$. Endocr. 55, 119-125

BOOTH, W.D. (1975). Changes with age in the occurrence of $\mathrm{C}_{19}$ steroids in the testis and submaxillary gland of the boar. J. Reprod. Fert. 42, 459-472

BOOTH, W.D. (1977). Metabolism of androgens in vitro by the submaxillary salivary gland of the mature domestic boar. J. Endocr. 75, 145-154

BOOTH, W.D. (1980a). A study of some major testicular steroids in the pig in relation to their effect on the development of male characteristics in the prepubertally castrated boar. J. Reprod. Fert. 59, 155-162

BOOTH, W.D. (1980b). Endocrine and exocrine factors in the reproductive behaviour of the pig. Symp. Zool. Soc. Lond. 45, 289-311

BOOTH, W.D. and JONES, R. (1980). The extragonadal origin of $5 \alpha$-reduced androgens in the peripheral circulation of the adult male rabbit. Int. $J$. Androl. 3, 692-702

BOOTH, W.D. and POLGE, C. (1976). The occurrence of $\mathrm{C}_{19}$ steroids in testicular tissue and submaxillary glands of intersex pigs in relation to morphological characteristics. J. Reprod. Fert. 46, 115-121

BOOTH, W.D., HAY, M.F. and DOTT, H.M. (1973). Sexual dimorphism in the submaxillary gland of the pig. J. Reprod. Fert. 33, 163-166

BROPHY, P.J. and GOWER, D.B. (1972). 16-unsaturated $\mathrm{C}_{19}$ 3-oxo-steroids as metabolic intermediates in boar testis. Biochem. J. 128, 945-952

BROPHY, P.J. and GOWER, D.B. (1974). Studies on the inhibition by $5 \alpha-$ pregnane-3,20-dione of the biosynthesis of 16-androstenes and dehydroepiandrosterone in boar testis preparations. Biochim. Biophys. Acta 360, 252-259

BUSCH, W. and ITTRICH, G. (1968). Untersuchungen über die Ostrogenausscheidung beim Eber. Endokrinologie 53, 100-105 
CALlARD, G.V., PETRO, Z. and RYAN, K.J. (1978). Phylogenetic distribution of aromatase and other androgen-converting enzymes in the central nervous system. Endocrinology 103, 2283-2290

CARLSTROM, K., MALMFORS, B., LUNDSTROM, K., EDOUIST, L.E. and GAHNE, B. (1975). The effect of HCG on blood plasma levels of $5 \alpha$-androstenone and testosterone in the boar. Swed. J. agric. Res. 5, 15-21

ClAUS, R. (1970). Bestimmung von Testosteron und $5 \alpha$-androst-en-3-on, einen Ebergeruchsstoff, bei Sweinen. Dr. agr. thesis. Technical High School, Munich

CLAUS, R. (1975). Neutralization of pheromones by antisera in pigs. In Immunization with Hormones in Reproductive Research, (E. Nieschlag, Ed.), pp. 189-197. Amsterdam, North Holland Publishing Company

ClAUS, R. (1979). Pheromone bei Säugetieren unter besonderer Berlicksichtigung des Ebergeruchsstoffes und seiner Beziehung zu anderen Hodensteroiden. Adv. Anim. Nutr. 10, 1-136

CLAUS, R. and GIMENEZ, T. (1977). Diurnal rhythm of $5 \alpha$-androst-16-en-3one and testosterone in peripheral plasma of boars. Acta endocr. 84, 200-206

ClAAUS, R. and HOFFMANN, B. (1980). Oestrogens, compared to other steroids of testicular origin in blood plasma of boars. Acta endocr. 94, 404-411

ClAUS, R., HOFFMANN, B. and KARG, H. (1971). Determination of $5 \alpha$ androst-16-en-3-one, a boar taint steroid in pigs, with reference to relationships to testosterone. J. Anim. Sci. 33, 1293-1297

COLENBRANDER, B., DE JONG, F.H. and WENSING, C.J.G. (1978). Changes in serum testosterone concentrations in the male pig during development. J. Reprod. Fert. 53, 377-380

COOKE, G.M. and GOWER, D.B. (1977). The submicrosomal distribution in rat and boar testis of some enzymes involved in androgen and 16androstene biosynthesis. Biochim. Biophys. Acta 498, 265-271

DAVIS, B.J. (1964). Disc electrophoresis. Method and application to human serum proteins. Ann. N.Y. Acad. Sci. 121, 404-427

DUFOUR, J. and RAESIDE, J.I. (1968). Histochemical demonstration of $\triangle^{5}-3 \beta$ - and $17 \beta$-hydroxysteroid dehydrogenases in the testes of the boar.

J. Reprod. Fert. 16, 123-124

ECHTERNKAMP, S.E., TEAGUE, H.S., PLIMPTON, R.F. and GRIFO, A.P. (1969). Glandular development, hormonal response and boar odor and flavor intensity of untreated and diethylstilbestrol implanted boars. J. Anim. Sci. 28, 653-658

ELLENDORFF, F., PARVIZI, N., POMERANTZ, D.K., HARTJEN, A., KÖNIG, A., SMIDT, D. and ELSAESSER, F. (1975). Plasma luteinizing hormone and testosterone in the adult pig: 24 hour fluctuations and the effect of copulation. J. Endocr. 67, 403-410

ELSAESSER, F., KÖNIG, A. and SMIDT, D. (1972). Der testosteron und androstendiongehalt im eberhoden in abhängigkeit vom alter. Acta endocr. 69, 553-566

ELSAESSER, F., ELLENDORFF, F., POMERANTZ, D.K., PARVIZI, N. and SMIDT, D. (1976). Plasma levels of luteinizing hormone, progesterone, testosterone and $5 \alpha$-dihydrotestosterone in male and female pigs during sexual maturation. J. Endocr. 68, 347-348

ENGEL, L.L. (1973). The biosynthesis of oestrogens. In Handbook of 
Physiology, 2, Sect. 7, Part 1, (R.O. Greep and S.R. Geiger, Eds.), p. 467. Washington, American Physiological Society

FISH, D.E., COOKE, G.M. and GOWER, D.B. (1980). Investigation into the

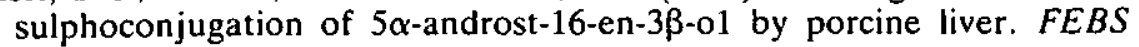
Lett. 117, 28-32

FLOOD, P.F. (1973). Histochemical localization of hydroxysteroid dehydrogenases in the maxillary glands of pigs. $J$. Reprod. Fert. 32, 125-127

FORD, J.J. and SCHANBACHER, B.D. (1977). Luteinizing hormone secretion and female lordosis behaviour in male pigs. Endocrinology 100, 10331038

FORD, J.J., CHRISTENSEN. R.K. and MAURER, R.R. (1980). Serum testosterone concentrations in embryonic and fetal pigs during sexual maturation. Biol. Reprod. 23, 583-587

FORLUND, D.M., LUNDSTROM, K. and ANDRESEN, O. (1980). Relationship between androstenone content in fat, intensity of boar taint and size of accessory sex glands in boars. Nord. VetMed. 32, 201-206

FOWLER, V.R. (1976). Some aspects of the use of anabolic steroids in pigs. In Anabolic Agents in Animal Production, (F.C. Lu and J. Rendel, Eds.), p.109. Stuttgart, Georg Thieme

GASPARINI, F.J., HOCHBERG, R.B. and LIEBERMAN, S. (1976). Biosynthesis of steroid sulfates by the boar testes. Biochemistry 15, 3969-3975

GOWER, D.B. (1972). 16-unsaturated $C_{19}$ steroids. A review of their chemistry, biochemistry and possible physiological role. J. Ster. Biochem. 3, 45-103

GOWER, D.B. and AHMAD, N. (1967). Studies on the biosynthesis of 16dehydrosteroids. The metabolism of $\left(4-{ }^{14} \mathrm{C}\right)$ pregnenolone by boar adrenal and testis in vitro. Biochem. J. 104, 550-556

GOWER, D.B. and LOKE, K.H. (1971). Studies on the subcellular location and stability of the enzyme system involved in the biosynthesis of 5,16androstadien-3 $\beta$-ol from $3 \beta$-hydroxy-5-pregnen-20-one (pregnenolone). Biochim. Biophys. Acta 250, 614-616.

GOWER, D.B., HARRISON, F.A. and HEAP, R.B. (1970). The identification of $C_{19}$ 16-unsaturated steroids and estimation of 17-oxosteroids in boar spermatic vein plasma and urine. J. Endocr. 47, 357-368

GRAY, R.C., DAY, B.N., LASLEY, J.F. and TRIBBLE, L.F. (1971). Testosterone levels of boars at various ages. J. Anim. Sci. 33, 124-126

HENRICKS, D.M., GUTHRIE, H.D. and HANDLIN, D.L. (1972). Plasma oestrogen, progesterone and luteinizing hormone levels during the oestrous cycle in pigs. Biol. Reprod. 6, 210-218

HOFFMANN, B., CLAUS, R. and KARG, H. (1970). Bestimmung von Testosteron im peripheren blut von Schwein und rind mit einer DoppelisotopenderivatVerdünnungsmethode. Acta endocr. 64, 377-384

HUIS IN'T VELD, L.G., LOUWERENS, B. and REILINGH, w. (1964). The origin of urinary dehydroepiandrosterone in boars. Acta Endocr. 46, 185-196 INANO, H. and TAMAOKI, B. (1975). Relationship between steroids and pyridine nucleotides in the oxido-reduction catalyzed by the $17 \beta$ hydroxysteroid dehydrogenase purified from the porcine testicular microsomal fraction. Eur. J. Biochem. 53, 319-326

JARMOLUK, L., MARTIN, A.H. and FREDEEN, H.T. (1970). Detection of taint (sex odour) in pork. Can. J. Anim. Sci. 50, 750-752 
JONSSON, P. and ANDRESEN, O. (1979). Experience during two generations of within lines boar performance testing, using $5 \alpha$-androst-16-ene-3-one $(5 \alpha$-androstenone) and an olfactory judgement of boar taint. Annls Genet. Select. anim. 11, 241-250

JOSHI, H.S. (1971). Synergistic effects of testosterone and oestrogens on male accessory glands of castrated rats and boars. PhD Thesis. University of Guelph

JOSHI, H.S. and RAESIDE, J.I. (1973). Synergistic effects of testosterone and oestrogens on accessory sex glands and sexual behaviour of the boar. $J$. Reprod. Fert. 33, 411-423

KALLA, N.R., NISULA, B.C., MENARD, R. and LORIAUX, D.L. (1980). The effect of estradiol on testicular testosterone biosynthesis. Endocrinology 106, 35-39

KATKOV, T. and GOWER, D.B. (1970). The biosynthesis of androst-16-enes in boar testis tissue. Biochem. J. 117, 533-538

KATKOV, T., BOOTH, W.D. and GOWER, D.B. (1972). The metabolism of 16-androstenes in boar salivary glands. Biochim. Biophys. Acta 270, 546-556

KAUFMAN, G. and SCHUBERT, K. (1980). Inhibition of 16-androstene biosynthesis in boar testis preparations by known and new steroids. $J$. Ster. Biochem. 13, 351-358

KAUFMAN, G., RITTER, F. and SCHUBERT, K. (1976). Quantitative determination of the boar taint substance $5 \alpha$-androst-16-en-3-one in fat. J. Ster. Biochem. 7, 593-597

KAUR, C. and MANGAT, H.K. (1980). Effects of estradiol dipropionate on the biochemical composition of testis and accessory sex organs of adult rats. Andrologia 12, 373-378

KLOEK, J. (1961). The smell of some steroid sex-hormones and their metabolites. Reflections and experiments concerning the significance of smell for the mutual relation of the sexes. Folia psychiat. neurol. neurochir. neerl. 64, 309-344

KROES, R., HUIS IN'T VELD, L.G., SCHULLER, P.L. and STEPHANY, R.W. (1976). Methods for controlling the application of anabolics in farm animals. In Anabolic Agents in Animal Production, (F.C. Lu and J. Rendel, Eds.), p.192. Stuttgart, Georg Thieme

LAPWOOD, K.R. and FLORCRUZ, S.V. (1978). Luteinizing hormone and testosterone secretory profiles of boars: effects of stage of sexual maturation. Theriogenology 10, 293-306

LINDE, C., EINARSSON, S. and GUSTAFSSON, B. (1975). The effect of exogenous administration of oestrogens on the function of the epididymis and the accessory sex glands in the boar. Acta vet. scand. 16, 456-464

LINDNER, H.R. (1960). Testicular endocrine function in domestic animals. PhD Thesis. Cambridge University

LINDNER, H.R. (1961). Androgens and related compounds in the spermatic vein blood of domestic animals. J. Endocr. 23, 171-178

LIPTRAP, R.M. and RAESIDE, J.I. (1970). Urinary steroid excretion in cryptorchidism in the pig. J. Reprod. Fert. 21, 293-301

LIPTRAP, R.M. and RAESIDE, J.I. (1971). Urinary steroid excretion in response to endogenous and exogenous gonadotrophin stimulation of cryptorchid testes in the pig. J. Reprod. Fert. 25, 55-60 
LIPTRAP, R.M. and RAESIDE, J.I. (1972). Effect of gonadotrophin stimulation on urinary steroid excretion after relocation of normal and cryptorchid testes in the boar. J. Reprod. Fert. 30, 465-467

LIPTRAP, R.M. and RAESIDE, J.I. (1975). Increase in plasma testosterone concentration after injection of adrenocorticotrophin into the boar. $J$. Endocr. 66, 123-131

LIPTRAP, R.M. and RAESIDE, J.I. (1978). A relationship between plasma concentrations of testosterone and corticosteroids during sexual and aggressive behaviour in the boar. $J$. Endocr. 76, 75-85

LUNAAS, T. and VELLE, W. (1965). The effect of gonadotropins and synthetic gestagens on testicular steroid secretion in swine. Acta endocr. Suppl. 100,41

LUNDSTRÖM, K.. MALMFORS, B. and HANSSON, I. (1973). A simple biopsy technique for obtaining fat and muscle samples from pigs. Swed. J. agric. Res. 3, 211-213

LUNDSTRÖM, K., MALMFORS, B., HANSSON, I., EDQVIST, L.E. and GAHNE, B. (1978). $5 \alpha$-androstenone and testosterone in boars. Early testing with HCG, sexual stimulation and diurnal variation. Swed. J. agric. Res. 8, $171-180$

LUNDSTRÖM, K., HANNSON, K.-E., FJELKNER-MODIG, S. and PERSSON, J. (1980). Skatole-another contributor to boar taint. Meeting of Meat Research Workers, Colorado Springs, USA Abstract F13

MALMFORS, B. and ANDRESEN, O. (1975). Relationship between boar taint intensity and concentration of $5 \alpha$-androst-16-en-3-one in boar peripheral plasma and back fat. Acta agric. scand. 25, 92-96

MALMFORS, B., LUNDSTRÖM, K., HANSSON, I. and GAHNE, B. (1976). The effect of $\mathrm{HCG}$ and $\mathrm{LH}-\mathrm{RH}$ on $5 \alpha$-androstenone levels in plasma and adipose tissue of boars. Swed. J. agric. Res. 6, 73-79

MASON, J.I., PARK. R.J. and BOYD, G.S. (1979). A novel pathway of androst16-ene biosynthesis in immature pig testis microsomal fractions. Biochem. Soc. Trans. 7, 641-643

MELROSE, D.R., REED, H.C.B. and PATTERSON, R.L.S. (1971). Androgen steroids associated with boar odour as an aid to the detection of oestrus in pig artificial insemination. Br. vet. J. 127, 497-501

MOON, Y.S. and RAESIDE, J.I. (1972). Histochemical studies on hydroxysteroid dehydrogenase activity of fetal pig gonads. Biol. Reprod. 7, 278-287

MORAli, G., LARSSON, K., PEREZ-PALACIOS, G. and BEYER, C. (1974). Testosterone, androstenedione, and androstenediol: effects on the initiation of mating behaviour of inexperienced castrated rats. Horm. Behav. 5, 103-110

MORAT, M. and COURTY, Y. (1979). Dosage simultane, par radioimmunologie, de l'androstenedione, de la testosterone et de la dihydrotestosterone. Application a l'etude du fonctionnement des cellules de Leydig. $C$. r. Seanc. Soc. biol., Paris 173, 1070-1077

NOTATION, A.D. and UNGAR, F. (1969). Regulation of rat testis steroid sulfatase. A kinetic study. Biochemistry 8, 501-506

PARKES, A.S. (1966). The testes of certain Chaeromorpha. Symp. Zool. Soc. Lond. 15, 141-154

PARROTT, R.F. (1978). Courtship and copulation in prepubertally castrated male sheep (wethers) treated with 17 $\beta$-estradiol, aromatizable androgens, or dihydrotestosterone. Horm. Behav. 11, 20-27 
PARVIZI, N., ELSAESSER, F., SMIDT, D. and ELLENDORFF, F. (1977). Effects of intracerebral implantation, microinjection, and peripheral application of sexual steroids on plasma luteinizing hormone levels in the male miniature pig. Endocrinology 101, 1078-1087

PATTERSON, R.L.S (1968a). Identification of $3 \alpha$-hydroxy-5 $\alpha$-androst-16-ene as the musk odour component of boar submaxillary salivary gland and its relationship to the sex odour taint in pork meat. J. Sci. Fd Agric. 19, 434-438

PATTERSON, R.L.S. (1968b). 5 $\alpha$-androst-16-ene-3-one:- compound responsible for taint in boar fat. J. Sci. Fd Agric. 19, 31-38

PAYNE, A.H. and JAFFE, R.B. (1970). Comparative roles of dehydroepiandrosterone sulfate and androstenediol sulfate as precursors of testicular androgens. Endocrinology 87, 316-322

PELLINIEMI, L.J. (1976). Ultrastructure of the indifferent gonad in male and female pig embryos. Tiss. Cell 8, 163-174

PERRY, G.C., PATTERSON, R.L.S., MacFIE, H.J.H. and STINSON, C.G. (1980). Pig courtship behaviour: pheromonal property of androstene steroids in male submaxillary secretion. Anim. Prod. 31, 191-199

PITZEL, L., HARTIG, A., HOLTZ, W. and KÖNIG, A. (1980). Plasma corticosteroid, testosterone and LH levels after ACTH injection in male pigs. Acta Endocr. Suppl. 234, 35-36

PRELOG, V. and RUZICKA, L. (1944). Über zwei moschusartig riechende Steroide aus Schweinetestes-Extracten. Helv. Chim. Acta 27, 61-66

RAESIDE, J.I. (1965). Urinary excretion of dehydroepiandrosterone and oestrogens by the boar. Acta endocr. 50, 611-620

RAESIDE, J.I. and HOWELLS, G.A. (1971). The isolation and identification of androstenediol sulfate from spermatic vein blood and testes of the boar. Can. J. Biochem. 49, 80-84

RAESIDE, J.I. and SIGMAN, D.M. (1975). Testosterone levels in early fetal testes of domestic pigs. Biol. Reprod. 13, 318-321

REED, H.C.B., MELROSE, D.R. and PATTERSON, R.L.S. (1974). Androgen steroids as an aid to the detection of oestrus in pig artificial insemination. Br. vet. J. 130, 61-67

RHODES, D.N. (1971). Consumer testing of bacon from boar and gilt pigs. $J$. Sci. Fd Agric. 22, 485-490

RHODES, D.N. (1972). Consumer testing of pork from boar and gilt pigs. $J$. Sci. Fd Agric. 23, 1483-1491

RICHARDS, G. and NEVILLE, A. (1973). Androgen metabolism in rat interstitial tissue and seminiferous tubules. Nature, Lond. 244, 359-361

ROBERTS, K.D., BANDI, L., CALVIN, H.I., DRUCKER, W.D. and LIEBERMAN, S. (1964). Evidence that steroid sulfates serve as biosynthetic intermediates. IV. Conversion of cholesterol sulfate in vivo to urinary $C_{19}$ and $C_{21}$ steroid sulfates. Biochemistry 3, 1983-1988

ROMMEL, P., OTTO, E. and BLÖDOW, G. (1975). Orientierungsversuche zur medikamentellen Beseitigung des Geschlechtsgeruches beim Eber. 3. Mitt: Intramuskulare Applikation von 19-Norathisteronazetat. $M h$. VetMed 30, 292-297

ROSSOUW, A.F., SKINNER, J.D. and KEMM, E.H. (1971). The effect of androstenedione on growth, carcass composition and reproductive development of porkers. S. Afr. J. Anim. Sci. 1, 85-89

RUOKONEN, A. (1978). Steroid metabolism in testis tissue: the metabolism 
of pregnenolone, pregnenolone sulfate, dehydroepiandrosterone and dehydroepiandrosterone sulfate in human and boar testes in vitro. $J$. Ster. Biochem. 9, 939-946

RUOKONEN, A. and VIHKO, R. (1974). Steroid metabolism in testis tissue: concentrations of unconjugated and sulfated neutral steroids in boar testis. J. Ster. Biochem. 5, 33-38

SAAT, Y.A., GOWER, D.B., HARRISON, F.A. and HEAP, R.B. (1972). Studies on the biosynthesis in vivo and excretion of 16-unsaturated $\mathrm{C}_{19}$ steroids in the boar. Biochem. J. 129, 657-663

SANFORD, L.M., SWIERSTRA, E.E., PALMER, W.M. and HOWLAND, B.E. (1976). The profile of luteinizing hormone and testosterone secretion in the boar. VIII Int. Congr. Anim. Reprod. A.I., Kracow 3, 96-99

SCHILLING, E. and LAFRENZ, R. (1977). Östrogengaben an männliche Saugferkel und die Wirkung auf Hodenentwicklung und Androgenproduktion zur Zeit der Geschlechtsreife. Zuchthygiene 12, 145-151

SEGAL, D.H. and RAESIDE, J.I. (1975). Androgens in testes and adrenal glands of the fetal pig. J. Ster. Biochem. 6, 1439-1444

SETCHELL, B.P. (1978). Endocrinology of the testis. In The Mammalian Testis, (C.A. Finn, Ed.), pp. 109-180. London, Paul Elek

SHIMIZU, K. (1978). Formation of $5-\left[17 \beta{ }^{2} \mathrm{H}\right]$ androst-3 $\beta, 17 \alpha$-diol from $3 \beta$-hydroxy-5-[17,21,21,21-2 $\mathrm{H}]$ pregnen-20-one by the microsomal fraction of boar testis. J. biol. Chem. 253, 4237-4241

SHIMIZU, K. and NAKADA, F. (1976). Formation of $\left[17-{ }^{2} \mathrm{H}\right]$ androsta-5,16dien-3 $\beta$-o1 from $\left[17,21,21,21{ }^{2} \mathrm{H}\right]$ pregnenolone by the microsomal fraction of boar testis. Biochim. Biophys. Acta 450, 441-449

SINK, J.D. (1967). Theoretical aspects of sex odor in swine. J. Theoret. Biol. 17, 174-180

STEWART, D.W. and RAESIDE, J.I. (1976). Testosterone secretion by the early fetal pig testes in organ culture. Biol. Reprod. 15, 25-28

STINSON, G.C. and PATTERSON, R.L.S. (1972). $C_{19}-\Delta^{16}$ steroids in boar sweat glands. Br. vet. J. 128, xli-xlii

TAN, H.S. and RAESIDE, J.I. (1980). Developmental patterns of plasma dehydroepiandrosterone sulfate and testosterone in male pigs. Anim. Reprod. Sci. 3, 73-81

VELLE, W. (1958a). Investigations on naturally occurring estrogens in ruminants and pigs. Thesis. Oslo

VELLE, W. (1958b). Further studies on urinary oestrogen excretion by the boar. Acta endocr. 29, 395-400

VELLE, W. (1966). Urinary oestrogens in the male. J. Reprod. Fert. 12, $65-73$

VELLE, W. (1976). Endogenous anabolic agents in farm animals. In Anabolic Agents in Animal Production, (F.C. Lu and J. Rendel, Eds.), p. 159. Stuttgart, Georg Thieme

WILleke, H., ClAus, R., PIRCHNER, F. and ALSING, W. (1980). A selection experiment against $5 \alpha$-androst-16-en-3-one, the boar taint steroid, in adipose tissue of boars. Z. Tierzücht. Zücht. Biol. 97, 86-94 